\title{
Changes in Soil Conditions Following Treatment with a Large Amount of Urea to Enhance Fungal Fruiting-body Production in a Japanese Red Pine Forest
}

\author{
TAKASHI YAMANAKA* \\ Laboratory of Applied Botany, Faculty of Agriculture, Kyoto University, \\ Kyoto 606-01, Japan
}

(Received February 22, 1995 - Accepted June 5, 1995)

Key words : ammonia fungi, soil bacteria, nematodes, urea treatment

There have been many reports of changes in fungal fruit-body flora following treatment of forest soil with chemicals or fertilizers ${ }^{2,6,9-11,15,16,24)}$. These reports are from an orchard, coniferous forests, and deciduous forests. According to these investigations, the number and kind of fungus species occurring after chemical treatment changed depending on vegetation, the intensity of treatment, and the type of substances added.

Communities of other soil-organisms, which are important as biotic factors in fruit-body production, as reported in Agaricus bisporus (Lange) Sing. ${ }^{31)}$ and some coprophilous fungi ${ }^{21)}$, would change after these chemical treatments. However, such changes in soil treated to enhance production of fleshy fungi have received little attention. Changes in populations of soil-organisms has been well documented after use of fertilizers ${ }^{1,4,12,20)}$. Among these reports, Franz and Loub ${ }^{4)}$ noted changes in fruit-body occurrence without referring to the period of the occurrence.

The "ammonia fungi" ${ }^{22)}$, a chemoecological group of fungi, develop sporophores sequentially on forest soil after treatment with ammonia water

* Present address: Forestry and Forest Products Research Institute, P.O. Box 16 Tsukuba Norin Kenkyu Danchi-nai, Ibaraki 305, Japan. or some ammonia-releasing substances, or after decomposition of dead bodies or faeces of animal. Until now approximately 35 species of ammonia fungi have been reported in Japan. In the U.K. and the U.S.A., this group of fungi have been observed after urea application ${ }^{11,23)}$. According to Sagara ${ }^{22)}$ and Suzuki ${ }^{29)}$, after urea treatment, litter became black and $\mathrm{NH}_{4}{ }^{+} \mathrm{N}$ concentration in soil increased, resulting in an increase in soil $\mathrm{pH}$ to $8-10$, and the water content increased ; afterwards, the $\mathrm{pH}$ value and $\mathrm{NH}_{4}{ }^{+}-\mathrm{N}$ concentration decreased to nearly normal, and water content often decreased below that of the control.

Treatment with nitrogenous materials as described above should also stimulate build up of other soil-organisms, and this in turn should affect changes in the previously-described soil parameters, and have an important effect on fungus occurrence. Furuya ${ }^{5)}$ isolated fungi from the soil treated with $1,000 \mathrm{~g} / \mathrm{m}^{2}$ of urea by plating, and most of the fungi obtained differed from those occurring on the soil surface and from those isolated from an untreated soil. In the present study I investigated changes in the numbers of bacteria and nematodes in soil treated with urea in relation to the occurrence of ammonia fungi, and changes in soil $\mathrm{pH}$, water content and $\mathrm{NH}_{4}{ }^{+}-\mathrm{N}$ concentra- 
tion.

The study was carried out in a 45-year-old Japanese red pine (Pinus densiflora Sieb. et Zucc.) forest at the Kamigamo Experimental Station of Kyoto University Forest $\left(35^{\circ} 04^{\prime} \mathrm{N}, 135^{\circ} 43^{\prime} \mathrm{E} ; 120\right.$ $140 \mathrm{~m}$ above sea level), about $12 \mathrm{~km}$ north of Kyoto City. Air temperature at the station in 1989 ranged from $4.2^{\circ} \mathrm{C}$ in December to $24.3^{\circ} \mathrm{C}$ in August, and annual rain fall was $1,430 \mathrm{~mm}$. The parent rock consists of Paleozoic sandstone and slate. The soil surface is covered with a litter layer $\left(\mathrm{A}_{0}\right)$, with three zones, i.e., $\mathrm{L}, \mathrm{F}$ and $\mathrm{H}$ layers. The $\mathrm{H}$ layer and mineral soil layer $\left(\mathrm{A}_{1}\right.$ layer) were fused together and the boundary between them was indistinguishable. The B layer was below an 8-13 cm depth.

Eleven plots, each $50 \mathrm{~cm}$ wide and $200 \mathrm{~cm}$ long, were marked out along a slope in the forest. Six such plots were each treated with $700 \mathrm{~g}$ of urea by hand-scattering on 10 April 1989; the remaining plots served as controls. After treatment, the occurrence of fungal fruit-bodies was observed. Soil sampling began on 10 April, 1989, in the control plots and on 17 April, 1989, in the ureatreated plots, and repeated 12 times in the first year, and then once or twice a year in the subsequent years until 21 October, 1991. Samples were collected from the organic soil $(\mathrm{F}+\mathrm{H})$ layer in five of the six urea-treated plots and in the five untreated plots.

Soil samples were thoroughly mixed and supplied for the following analyses. Soil $\mathrm{pH}$ was measured by a glass electrode after stirring $5 \mathrm{~g}$ fresh soil in $20 \mathrm{ml}$ distilled water for $3 \mathrm{~min}$. Water content was determined by oven-drying $5 \mathrm{~g}$ of fresh soil at $105^{\circ} \mathrm{C}$ for $5 \mathrm{hrs}$ and expressed as the

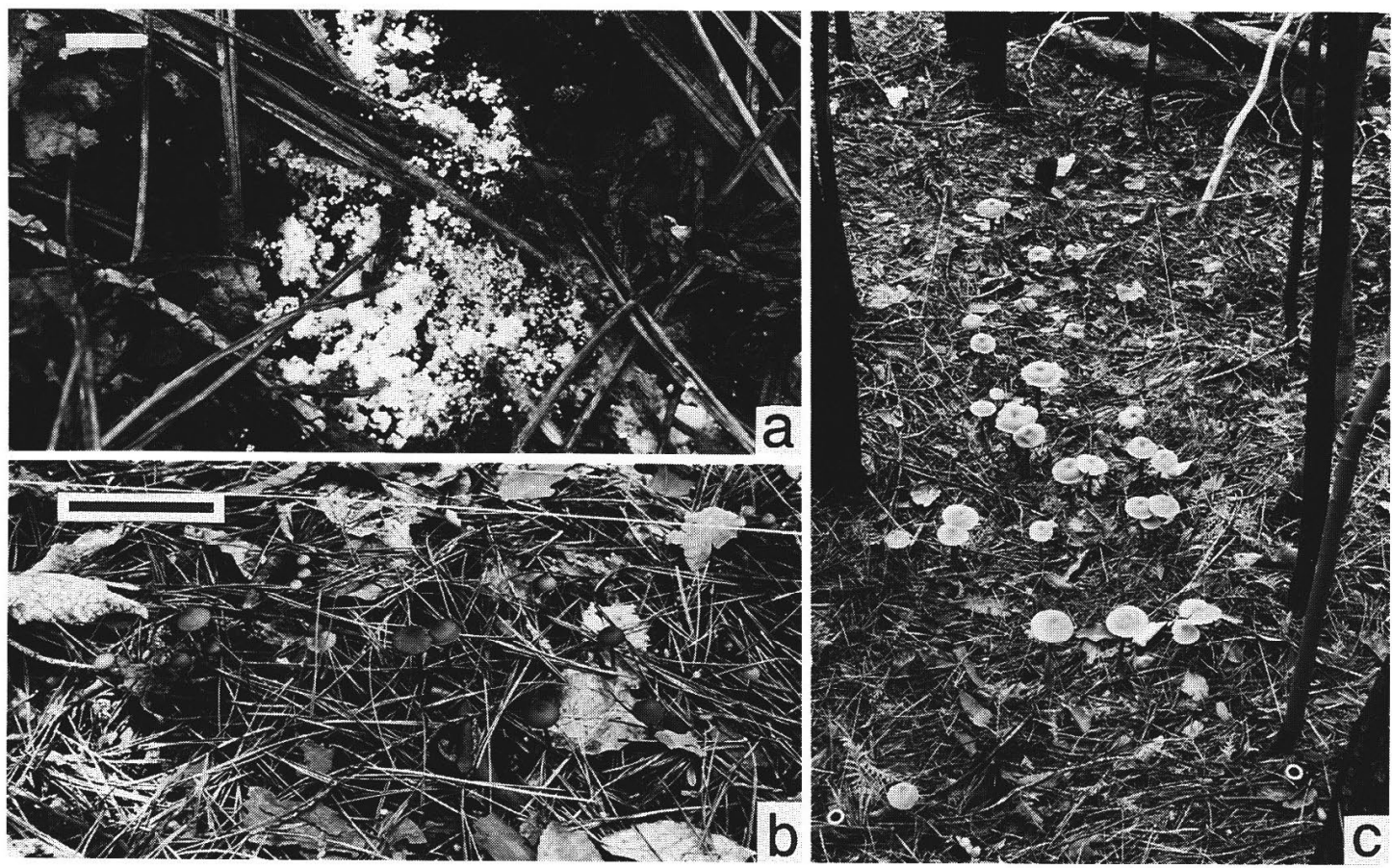

Fig. 1a-c. Fungi occurring in urea-treated $\left(700 \mathrm{~g} / \mathrm{m}^{2}\right)$ forest soil. a. Amblyosporium botrytis. Scale= $1 \mathrm{~cm}$. Photo on 3 May 1989. b. Lyophyllum tylicolor. Scale $=5 \mathrm{~cm}$. Photo on 29 May 1989. c. Laccaria bicolor. Fruiting was observed within the urea-treated plot $(50 \mathrm{~cm} \times 200 \mathrm{~cm})$ shown with white lines. Photo on 15 Oct. 1990. 
percentage of the weight of fresh soil. $\mathrm{NH}_{4}{ }^{+} \mathrm{N}$ was extracted by suspending $10 \mathrm{~g}$ of soil in $100 \mathrm{ml}$ of $2 \mathrm{~N} \mathrm{KCl}$ for $60 \mathrm{~min}$, and determined using the indophenol blue method of Keeney and Nelson ${ }^{7)}$. Bacteria were counted using $10 \mathrm{~g}$ of fresh soil by the dilution plate technique. Nematodes were extracted from $10 \mathrm{~g}$ of fresh soil using a modified Baermann funnel technique ${ }^{3)}$, and counted using a dissecting microscope.

The following species of fungi occurred successively in the urea-treated soil, i.e., Amblyosporium botryris Fres., Ascobolus denudatus Fr., Peziza moravecii (Svrček) Donadini, Peziza sp., Pseudombrophila deerata (Karst.) Seaver, Lyophyllum tylicolor (Fr.: Fr.) Lange and Sivertsen, Coprinus echinosporus Buller, Hebeloma vinosophyllum Hongo, Laccaria bicolor (Maire) Orton, Hebeloma sp. $^{25)}$, Mycena pura (Pers. : Fr.) Kummer and Collybia cookei (Bres.) J.D. Arnold (Figs 1 and 2). All were absent in the control plots, and all extept $M$. pura have been reported to be ammonia fungi ${ }^{23)}$. The occurrence of most ammonia fungi started from the periphery of the plot. The following changes in surface soil were concurrent with the occurrence of fungi. The litter turned blackish and smelled of ammonia soon after the urea was added. Within 6 months after the treat- ment, fine roots were newly growing there, and ectomycorrhizas had formed in some of the roots.

While the $\mathrm{pH}$ value of untreated (control) soils remained at 3.6-4.4 throughout the sampling period, $\mathrm{pH}$ in the urea-treated plots increased to 7.8 seven days after treatment (Fig. 3a) and remained at $\mathrm{pH} 7-8$ for the next 98 days, then declined to 4.5 at 191 days after treatment.

The water content of control plot soil ranged between 59 and $73 \%$ throughout the sampling period (Fig. 3b). The water content in the ureatreated plots was higher than that in the control plots for 434 days following urea treatment.

$\mathrm{NH}_{4}{ }^{+} \mathrm{N}$ concentration in the control plots ranged from 0.004 to $0.074 \mathrm{mg} \mathrm{N} / \mathrm{g}$ dry soil throughout the sampling period (Fig. 3c). Sixteen days after the addition of urea, the $\mathrm{NH}_{4}{ }^{+}-\mathrm{N}$ concentration rose to $15 \mathrm{mg} / \mathrm{g}$ dry soil and remained there until 142 days after treatment, thereafter it gradually declined to $0.02 \mathrm{mg} / \mathrm{g}$ dry soil by the end of the study period.

In the control plots, the number of bacteria ranged from $2.1 \times 10^{8}$ and $9.9 \times 10^{8} / \mathrm{g}$ dry soil throughout the sampling period (Fig. 3d). Eighty-six days after adding urea the number of bacteria rose to $2.4 \times 10^{11} / \mathrm{g}$ dry soil. The population then declined slowly to $9.7 \times 10^{8} / \mathrm{g}$ dry soil by

\section{Species}
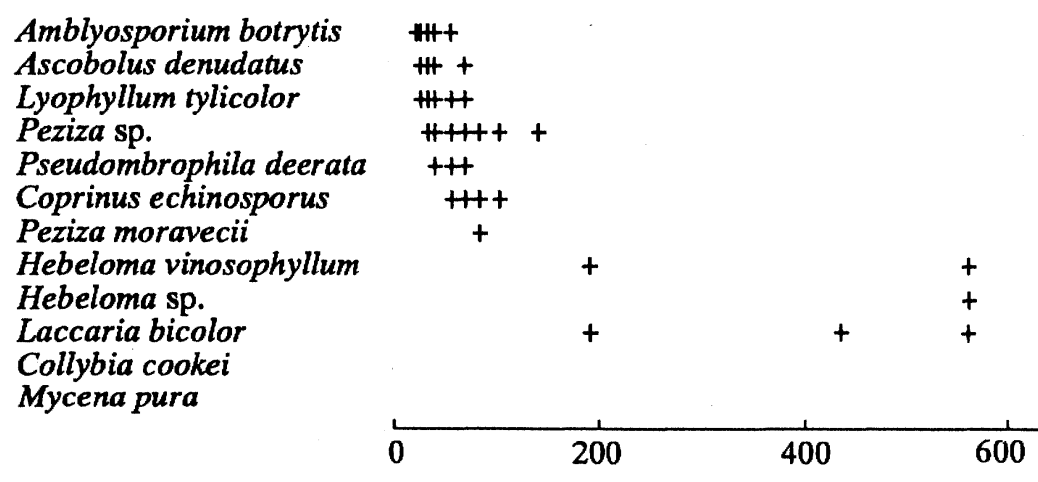

Days after treatment

Fig. 2. Occurrence of fungi $(+)$ in plots, where the forest soil was treated with $700 \mathrm{~g} / \mathrm{m}^{2}$ urea on April $10,1989$. 

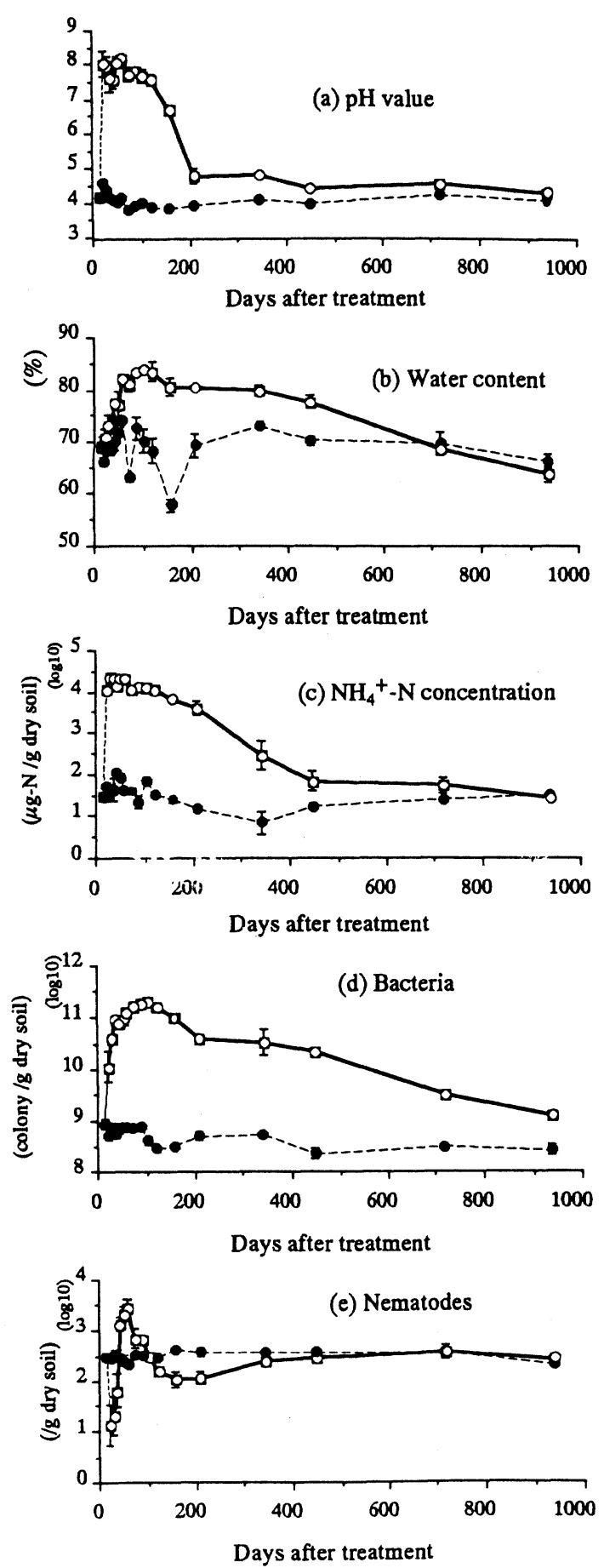

the end of the study period.

In the control plot, nematode numbers were between $170-312 / \mathrm{g}$ of dry soil throughout the sampling period (Fig. 3e). In the urea-treated plots the number of nematodes decreased dramatically soon after the addition of urea. In some extreme cases, the number temporarily dropped to zero. It then rose to $2,700 / \mathrm{g}$ dry soil 42 days after urea treatment, and then declined again to $94 / \mathrm{g}$ dry soil 191 days after the treatment. Most of the nematodes which increased after the urea addition were bacterium-feeding nematodes judged from the shape of their mouths.

At the end of the observation period, there were no significant ( $t$-test, $\mathrm{p}=0.05$ ) differences, except for the number of bacteria, in levels of any of the parameters in the treated and control plots $(n=5)$.

Urea is extensively employed for forestfertilization, and its effects on soil-organisms as well as soil $\mathrm{pH}$ and $\mathrm{N}$ content have been well studied $^{18-20,26)}$. In these studies urea addition resulted in an increase of soil $\mathrm{pH}$ and ammonium nitrogen and of soil microbial activity estimated by microbial respiration. In the present study, urea was applied at a higher rate than that for fertilization, and damaged the nematode population temporarily, but thereafter, nematodes and bacteria increased considerably (Figs $3 \mathrm{~d}$ and $3 \mathrm{e}$ ).

Ammonia was formed by urease soon after addition to soil. Although some of the increased ammonia might be lost by volatilization or by leaching after nitrification, that remaining should have been immobilized by soil-organisms, and then released via excretion or from their decomposed bodies. Thus, ammonia levels in the soil would remain high for a specific time after treatment (Fig. 3c). In laboratory experiments, ammonia in alka-

Fig. 3a-e. Changes in soil parameters following treatment with $700 \mathrm{~g} / \mathrm{m}^{2}$ of urea on 10 April 1989 . a soil $\mathrm{pH}$. b. soil water content. c. $\mathrm{NH}_{4}{ }^{+}-\mathrm{N}$ concentration. $d$. the number of bacteria. e. the number of nematodes. $\bigcirc-$, treated ; $-\cdots$, control. Values are the means of observations \pm the standard errors of the means. 
line conditions promotes spore germination, vegetative growth and fruit-body initiation in some ammonia fungi ${ }^{13,14,27,30)}$. In the present study, the direct effects of other microorganisms on the development of ammonia fungi were not examined, e.g., as reported for Agaricus bisporus where fruit-body initiation and hyphal growth were stimulated by some bacteria ${ }^{17,31)}$. Such microorganisms supposedly support the growth of ammonia fungi indirectly by maintaining high ammonia levels in the soil.

The increase in soil water content following urea treatment (Fig. 3b) may be due to the increase in the numbers of soil-organisms. Soil organisms could increase the water-holding capacity of soil by decomposing insoluble organic matters into particles. The increase in the fresh weight of the microbial population may also increase water content ${ }^{22}$.

It is not known how ammonia fungi survive in untreated field soil. Although their occurrence under natural conditions is rare $^{22)}$, they can be readily isolated from the tissue of fruit-bodies, or by germinating spores. In pure culture, without an excess supply of nitrogen, these fungi grow well and some of them fruit ${ }^{8,28)}$. These observations show that these fungi could exist as both mycelium and spores.

The ammonia fungi usually develop as follows ${ }^{22)}$. In the early stage, soon after urea treatment, imperfect fungi, cup fungi and smaller agarics appear for a short period; later, larger agarics appear. This pattern of fungus succession also occurred in the present study (Fig. 2). The early stage fungi appeared in response to high soil $\mathrm{NH}_{4}{ }^{+}-\mathrm{N}$ and $\mathrm{pH}$ (Figs 3a and 3c), which has been documented by an in vitro study ${ }^{29)}$. The late stage species might be considered as "pioneers in the recolonization of disturbed soils" 23 , because they were observed when the soil returned to an acidic condition (Fig. 3a) and fine roots which were killed by the treatment, had recovered. Many late stage fungi, i.e., Laccaria bicolor, Hebeloma spp., are mycorrhizal species, and likely form mycorrhizas with new roots. The sequence and timing of occurrence of each fungus is likely determined by other, yet unidentified endogenous and exogenous factors.

\section{Acknowledgement}

I thank Dr. N. Sagara, Kyoto University, for his valuable suggestions, and Dr. K. Futai, Kyoto University, for his advice on how to do the nematode analyses, and Dr. J.R. Sutherland, Pacific Forestry Centre of Canadian Forestry Service, Canada, for kindly correcting the manuscript.

\section{References}

1) Arnebrant, K., E. Bååth and B. Söderström. 1990. Changes in microfungal community structure after fertilization of Scots pine forest soil with ammonium nitrate or urea. Soil Biol. Biochem. 22 : 309-312.

2) Bond, T.E.T. 1972. Observations on the macrofungi of an apple orchard in relation to cover crops and NPK fertilizers. Trans. Br. mycol. Soc. 58 : 403-416.

3) Flegg, J.J.M. and D.J. Hooper, in "Laboratory Methods for Work with Plant and Soil Nematodes", 5th edn, ed. by J.F. Southey. Her Majesty's Stationary Office, London, 1970, pp. 5 $\sim 22$.

4) Franz, H. and W. Loub. 1959. Bodenbiologische Untersuchungen an Walddüngungsversuchen. Cbl. ges. Forstwesen. 76: 129-162.

5) Furuya, K. 1990. Coprophilous fungi as microbial resources. Annu. Rep. Sankyo Res. Lab. 42: $1-31$.

6) Hora, F.B. 1958. Effect of lime on the production of a toadstool (Omphalia maura (Fr.) Gill.). Nature 181: 1668-1669.

7) Keeney, D.R. and D.W. Nelson, in "Methods of Soil Analysis: Chemical and Microbiological Properties", 2nd edn, ed. by A.L. Page, R.H. Miller and D.R. Keeney. American Society of Agronomy, Madison, 1982, pp. 672 676.

8) Khan, A.Z.M. Nowsher A. 1977. Fruiting of Coprinus echinosporus in culture. Bull. Br. mycol. Soc. 11 : 146-147.

9) Kirsi, M. and P. Oinonen. 1981. Mushroom yields in 10-year-old coppice after spraying with MCPA. Karstenia 21 : 1-8.

10) Laiho, O. 1970. Paxillus involutus as a myco- 
rrhizal symbiont of forest trees. Acta For. Fenn. $106: 1-73$.

11) Lehmann, P.F. 1976. Unusual fungi on pine leaf litter induced by urea and urine. Trans. Br. mycol. Soc. 67 : 251-253.

12) Mai, H. and H.J. Fiedler. 1979. Microbiological investigations into soil in a fertilizer trial with spruce in the fume-damaged zone of the Erzgebirge. Zentbl. Bakteriol. 134: 651659.

13) Morimoto, N., S. Suda and N. Sagara. 1981. Effect of ammonia on fruit-body induction of Coprinus cinereus in darkness. Plant Cell Physiol. 22 : 247-254.

14) Morimoto, N., S. Suda and N. Sagara. 1982. The effects of urea on the vegetative and reproductive growth of Coprinus stercorarius in pure culture. Trans. Mycol. Soc. Jpn. 23 : 79-83.

15) Ohenoja, E. 1978. Mushrooms and mushroom yields in fertilized forests. Ann. Bot. Fennici 15 : 38-46.

16) Petersen, P.M. 1970. Changes of the fungus flora after treatment with various chemicals. Bot. Tidsskr. 65 : 264-280.

17) Rainey, P.B. 1991. Effect of Pseudomonas putida on hyphal growth of Agaricus bisporus. Mycol. Res. 95 : 699-704.

18) Roberge, M.R. 1976. Respiration rates for determining the effects of urea on the soil-surface organic horizon of a black spruce stand. Can. J. Microbiol. 22: 1328-1335.

19) Roberge, M.R. and R. Knowles. 1966. Ureolysis, immobilization, and nitrification in black spruce (Picea mariana Mill.) humus. Soil Sci. Soc. Amer. Proc. 30 : 201-204.

20) Roberge, M.R. and R. Knowles. 1967. The ureolytic microflora in a black spruce (Picea mariana Mill.) humus. Soil Sci. Soc. Amer. Proc. 31: 76-79.

21) Safar, H.M. and R.C. Cooke. 1988. Interactions between bacteria and coprophilous Ascomycotina and a Coprinus species on agar and in copromes. Trans. Br. mycol. Soc. 91 : 73-80.

22) Sagara, N. 1975. Ammonia fungi - a chemoecological grouping of terrestrial fungi. Contr. Biol. Lab. Kyoto Univ. 24 : 205-276.

23) Sagara, N, in "The Fungal Community: Its Organization and Role in the Ecosystem", 2nd edn, ed. by G.C. Carroll and D.T. Wicklow. Marcel Dekker, New York, 1992, pp. 427 454.

24) Sagara, N. and M. Hamada. 1965. Responses of higher fungi to some chemical treatments of forest ground. Trans. Mycol. Soc. Jpn. 6 : 72-74.

25) Sagara, N., H. Okabe and J. Kikuchi. 1993. Occurrence of an agaric fungus Hebeloma on the underground nest of wood mouse. Trans. Mycol. Soc. Jpn. 34 : 315-322.

26) Salonius, P.O. 1972. Microbiological response to fertilizer treatments in organic forest soils. Soil Sci. 114 : 12-19.

27) Suzuki, A. 1978. Basidiospore germination by aqua ammonia in Hebeloma vinosophyllum. Trans. Mycol. Soc. Jpn. 19 : 362.

28) Suzuki, A. 1979. General review on environmental factors affecting primordium formation in Homobasidiae. Trans. Mycol. Soc. Jpn. 20 : 253-265. (In Japanese)

29) Suzuki, A., in "Recent Advances in Microbial Ecology", ed. by T. Hattori, Y. Ishida, Y. Maruyama, R. Morita and A. Uchida. Scientific Society Press, Tokyo, 1989, 275 279.

30) Suzuki, A., N. Motoyoshi and N. Sagara. 1982. Effects of ammonia, ammonium salts, urea, and potassium salts on basidiospore germination in Coprinus cinereus and Coprinus phlyctidosporus. Trans. Mycol. Soc. Jpn. 23 : 217-224.

31) Wood, D.A. 1976. Primordium formation in axenic cultures of Agaricus bisporus (Lange) Sing. J. Gen. Microbiol. 95 : 313-323. 